\title{
NEMZETKÖZI MARKETING AZ ÁTALAKULÓ VILÁGBAN
}

\author{
KORREFERÁTUM REKETTYE GÁBOR \\ A „A HATALMI ÁTALAKULÁS GLOBÁLIS MEGATRENDJE ÉS \\ A NEMZETKÖZI MARKETING” CÍMÜ TANULMÁNYÁHOZ
}

A nemzetközi marketing a marketingtudomány dinamikusan változó része. Rekettye professzor cikkben összegezte gondolatait e tudományterület fejlódéséról és fontosságáról. Cikke egyértelmúen fogalmaz, ám néhány fontos kérdés tárgyalására nem kerített sort. $\mathbf{E}$ reagáló cikkben a szerzó a nemzetközi marketing és a világgazdaság, a demográfiai változások és a technológiai kihívások kapcsolatát elemezte, bemutatva, hogy e tényezők miként befolyásolják a nemzetközi marketing szerepét, jelentőségét, jövőjét, s ezzel kiegészítette az eredeti cikk gondolatait.

Kulcsszavak: világgazdasági átalakulás, demográfiai kihívások, vallás, technikai fejlódés, személyközpontú marketing

Nem könnyú és a magyar marketing szakmai gyakorlatában példa nélkül álló kezdeményezés indult el azzal, hogy egy felkért szerző cikkére mások reagáljanak, folytassák, kiegészítsék gondolatait, vitatkozzanak vele. Magam is abba a helyzetbe kerültem, hogy egy kitűnő kutató, Rekettye Gábor professzor inspiráló gondolatait kellett átolvasnom, s elemeznem. Mi lesz veled, nemzetközi marketing, egy változó világban? Ezt a kérdést tette fel a Szerzó, s levezetésével bizonyította, hogy a nemzetközi marketing szerepe, jelentősége egyre nagyobb lesz a világgazdaságban, hiszen olyan földrajzi és gazdasági területeken is megjelenik, ahol korábban erre nem igazán volt példa. A cikk érvelése és következtetései világosak, mégis úgy vélem, tudok olyan szempontokat felvillantani, amelyek talán más összefüggésbe helyezik a kérdést, és új kétségeket, dilemmákat fogalmaznak meg.

\section{A világgazdaság és a nemzetközi marketing kapcsolata}

Egyértelmú, hogy a XX. század vége, a XXI. század eleje új fejlemények sorozatát jelentette és jelenti a világgazdaság számára. 30-40 évvel ezelőtt viszonylag egyszerú volt a képlet. Nyugat-Európa, Japán és az Amerikai Egyesült Államok gazdasága „mindent vitt”, a gazdasági fejlódés centrumai a második világháború utáni európai kapitalista országok, a győzelemben nagy szerepet játszó USA, s a vesztesként nyertessé vált Japán voltak. A fogyasztás - ellentétben a szovjet blokkal - dinamikusan növekedett, s ez a piaci verseny erősödésével, ezzel párhuzamosan a marketing társadalmi-gazdasági jelentőségének növekedésével járt együtt. Amit ma marketingnek tekintünk, amiről előadásaink az egyetemeken szólnak, lényegében ebben a korszakban alakult ki. McCarthy (1960) vagy Kotler (1972) marketingértelmezései nem véletlenül váltak egyeduralkodóvá, paradigmává. Körülhatárolták a marketingtudomány múködési területeit, rögzítették azokat a fix pontokat (1. 4P, marketingkutatás, STP, 5M stb.), amelyektôl hosszú évtizedek távolában sem tudunk megszabadulni.

Kísérletet tettek a nemzetközi marketing fogalomrendszerének megalkotására is. Ám mivel múködésük területe mégiscsak a nemzetköziesedésben nem jeleskedő, az európainál sokkal zártabb gazdaságú Egyesült Államok volt, így nem tettek mást, mint az általános marketing fogalomrendszerét lényegében változtatás nélkül átültették a nemzetközi marketingbe oly módon, hogy megpróbálták harmonizálni saját nézőpontjukat, a jövőkutatók trendjeit, a világgazdaságról alkotott véleményüket, miközben az amerikai szemléletmódot te- 
kintették a jövőbeni „fejlődés” szilárd alapjának, és az egyedül üdvözítő útnak. Jellemző, hogy az angolszász területen később megszületett, mértékadó nemzetközimarketing-kötetek lényegében a kotleri fogalomrendszer és tankönyvszerkezet mutációjának tekinthetők (pl. Czinkota et al., 2013; Cateora et al., 2013), amelyekben a példák persze mindig újabbak, ám az elméleti megközelítés iránya változatlan.

Meglepő módon gondolataiknak kevés és erőtlen alternatívája született (4C- Lauterborn, 1990; SDL, Vargo - Lusch, 2004). Mindenki természetesnek vélte, hogy az irány helyes és világos. A gazdasági siker helyszíne, a követendó példa az USA, elóbb-utóbb mindenhol az amerikai gondolkodók szerint múködik majd a világgazdaság. Mindezt tetézte az, hogy a többi gyors fejlódésú gazdasági centrum (Japán, Nyugat-Európa) kutatói is úgy gondolták, hogy az amerikai piacszervezési, versenyszabályozási, marketingtudományi, menedzsmenti elvek és módszerek dominanciája megkérdőjelezhetetlen, különösen annak tükrében, hogy a keleti, kommunista blokk életképtelensége egyre nyilvánvalóbbá vált.

Ha egy kézilabda-bajnokságban - mint például a magyarban - csak két komoly csapat van, hamar odakoncentrálódik a figyelem, s nem igazán veszünk tudomást a többi szereplő́ről. Ez történt a világgazdaságban is. Sokáig nem tûnt fel a távol-keleti „,kis tigrisek” vagy az olajbirtokló Arábia felemelkedése. Amikor pedig felfigyeltünk rájuk, azt láttuk, amit látni szerettünk volna. A sikerre Amerikában kerestük a magyarázatot, s úgy véltük, hogy az amerikai elvek és megoldások mechanikus átvétele eredményezte e térségek felemelkedését. Nem vettünk, sokszor ma sem veszünk tudomást arról, hogy itt másról van szó. Ez egy olyan adaptáció, ahol az amerikai elvek mechanikus alkalmazása helyett a gazdaság minden területén, így a marketingben is új minőség született az adott országok társadalmi bázisán alapulva. Az 1980-as évek végétól a kelet-európai változások, a Szovjetunió felszámolódása megerősítette az amerikai út helyességének gondolatát, és máig nem elemezzük alaposan Kína, India, Latin-Amerika vagy újabban Afrika világgazdasági fejlődésének marketingtudományi következményeit. Mantraként ismételjük újra meg újra, hogy mindaz, amit látunk és tapasztalunk, levezethetô a saját korábbi elveinkből, marketingtudományi kutatásainkból és eredményeinkből, miközben nem gondolunk arra a tudományos hasonlatra, hogy a geocentrikus világkép alapján is nagyon jól leírható volt a bolygók és csillagok mozgása, de mégis a Föld kering a Nap körül. Mi van akkor, ha ez a marketingre is igaz? Tehát, ha a marketing - minden látszat ellenére - más a feltörekvő térségekben, mint máshol, egyszerúen azért, mert más társadalmi-gazdasági környezetben létezik.

Magam is sokat utaztam Ázsiában, Óceániában és a nemzetközi szakmai konferenciákon mindig érez- tem és érzek olyan különbségeket, amelyeket elsőre nehéz szavakba önteni, hiszen mindenki hasonló fogalomkészlettel operál, de mégis léteznek. Látszólag közös nevezőn vagyunk, de az adott előadás következő mondata elbizonytalanít. Tényleg létezik az a közös nevező, amelyen mindannyian ugyanazt értjük? S milyen lesz a nemzetközi marketing, ha a világgazdasági átrendeződés folytatódik, Kína vagy India, esetleg Latin-Amerika vagy Afrika felzárkózik? Ismét egy példával élve gondoljuk csak el: Bollywood filmjei „világhíresek” az indiai világban, miközben óriási bukásnak tekinthetôk minálunk. Pedig ugyanarról szólnak, mint az amerikai filmek; szerelemről, életről, halálról, sikerról, jóságról, gonoszságról. Mégis csak az adott környezetben múködnek, de ott aztán igazán.

Tehát dilemmák sorozata fogalmazódik meg bennem, ha a nemzetközi marketing jövőjére a világgazdaság oldaláról próbálok tekinteni. Jön-e valaki, aki robbantja a marketing-szakirodalmat egyszerúen azért, mert úgy érzi, hogy nem elég a meglévő paradigmák mentén gondolkodni, mint ahogy a holokauszt múvészi ábrázolása során ezt Kertész Imre az irodalomban a Sorstalanság, vagy Nemes Jeles András a filmmúvészetben a Saul fia révén tette? Vagy ugyanazok a sztereotípiák fogják meghatározni a nemzetközi marketinget, amelyek az utolsó negyven évet? Mi lenne akkor, ha például a környezetvédelem, a fenntartható fejlődés miatt megtorpanna a globalizáció és a világkereskedelem? Megváltozna-e a nemzetközi marketing kutatása, oktatása, vagy ez már elképzelhetetlen?

\section{Nemzetközi marketing a társadalmi-demográfiai változások tükrében}

A nemzetközi marketing tartalmát és szerepét véleményem szerint jelentősen befolyásolja az a demográfiai eltérés, amely Európát, Japánt vagy Kínát elválasztja a világ többi részétól. Míg ezek esetében a társadalom elöregedése, nemi kiegyensúlyozatlansága, adott esetben a népesség csökkenése figyelhető meg, addig a világ többi részén a fiatalok számának emelkedésével, a népesség növekedésével találkozunk. Ezen Európában a jelenlegi migránshelyzet sem tud majd lényegesen változtatni, miközben eltéró marketingmegoldások válnak elterjedtté egyik vagy másik közegben. Az elöregedő társadalmak elvezetnek-e a jóléti állam széthullásához, s ezen keresztül az időskori fogyasztás mértékének csökkenéséhez, vagy az ellenkezője következik be? Folytatódik-e a 18-49 év közötti korosztályok marketing „sztárolása” vagy netán az 50 felettieké is a világ? Ha igen, jelent-e ez változást a marketingeszközök használatában, vezet-e a marketingelmélet átalakulásához a világ különböző területein? 
Hasonlóan lényeges kérdésnek tartom a vallásosság és a szekularizáció folyamatainak hatását a nemzetközi marketingre, illetve a társadalmi-technológiai innovációra. A marketingtudomány és -gyakorlat utolsó száz éve olyan országokhoz kötődött szorosan, amelyek többségében a vallás szerepe megkérdőjeleződött, és ez együtt járt a korábbi „tiltott gyümölcsök” fogyasztásának fokozódásával. Az élet minden oldala üzletté válhatott, iparágak és szolgáltatások sora jelent meg, átalakítva az ember mindennapi életét. A szekularizált államokban élők klasszikus erkölcsi elveit egy pragmatikus, talán túlontúl pragmatikus, liberális szemléletmód váltotta fel. Ebben a világban például a böjt nem vallási, hanem életstílus kérdés, az ünnepek elsősorban piaci lehetőséget kínálnak, és vallási tartalmukon sokan inkább csak mosolyognak. De mi lesz akkor, ha ezekben az országokban is egyre eróteljesebb lesz az igény az új spirituális tartalmakra (lásd karizmatikus mozgalmak), vagy a tömeges bevándorlás révén átalakulnak a társadalmak, megnő az erőteljesen vallásos magatartású muszlimok száma, és szokásaik kihatnak az őslakosok mindennapi fogyasztási magatartására is? Jogosnak tekinthetjük-e az igényt a helyi kultúra elfogadására, vagy párhuzamos társadalmak jönnek létre, amelyek megkövetelik a marketinggyakorlat, és így a nemzetközi marketing gyakorlat átalakulását is? Mi van akkor, ha a nemzetközi marketing ezen keresztül normál, belső marketinggé válik, hiszen lehet, hogy egy országon belül kell majd ugyanazokat a marketingmegoldásokat követni, amelyeket eddig más országokban követtünk? Lesz-e ennek olyan következménye, hogy a társadalmi tabuk száma váratlanul megemelkedik, $\mathrm{s}$ nem azon gondolkodunk majd, hogy mit mondjunk egy marketingkampányban, hanem, hogy mit nem mondhatunk?

Valójában ezek a kérdések nem csupán technikai jellegúek. Átalakíthatják, átformálhatják a nemzetközi marketing eszköztárán túl az elméletét is.

\section{A technika és a személyközpontúság szerepe a nemzetközi marketingben}

A nemzetközi marketing általam most felvetett utolsó kérdésköre a nemzetközi marketing technikai elemeihez, illetve az egyénekhez szóló speciális megoldásokhoz kapcsolódik. A számítástechnika, az internet, az egyre gyorsabb és hatékonyabb logisztikai megoldások, a média technikai sokszínúsége, a közösségi színterek megjelenése és térhódítása átalakítja a nemzetközi marketing lehetôségeit, feladatait és módszereit. Hoszszú ideig feltételezhettük, hogy egy adott piacra történő belépés majdnem egyenlő a teljes ismeretlenségből való megjelenéssel. Ma ez már nincs így. Az információkhoz való hozzájutás ideje lerövidült, költsége minimálissá vált. Ennek eredményeként számos marketingalapelv sérült. Ma egy termék világméretű bevezetése néhány hónap vagy hét kérdése, az informatív reklám idôtartama pár nap, a szisztematikus marketingkutatás helyét nagy cégeknél (lásd Wizzair, Ryanair) is a próbálgatás vette át, nem piaciszegmens-elemzés, hanem piaciszegmens-teremtés folyik, az X és Z generációk közötti technikai tudásban rejlő eltérés, különbség óriási és így tovább. Ennek eredményeként lassan nem alap nélküli nemzetközi on-line marketingról beszélni, illetve a marketing és az információtudomány egyre szorosabb kapcsolatáról cikkezni a nemzetközi kapcsolatokat illetóen.

Ugyanakkor az a kérdés is felmerül, hogy miként a rákgyógyászatban az egyéni terápia, úgy a marketingben az egyszemélyes piaci megközelítés is életképes még a nemzetközi piacokon is. Mi lesz a klasszikus média jövője, ha az emberekhez egyénre szabott üzenetekkel könnyebb, olcsóbb és hatékonyabb lesz eljutni, mint az eddigi megoldásokkal? Ennek eredményeként sérülhet-e a szólásszabadság, mivel senki nem finanszírozza majd az oknyomozó, független sajtót? Izgalmas kérdés, mivel felvetése azt mutatja, hogy a marketing átalakulása egyértelmú hatást gyakorolhat nemcsak a fogyasztásra, de a demokrácia alakulására is. Érdemes-e például a nemzetközi marketing oktatása és kutatása során arra koncentrálnunk, hogy a klasszikus megoldások helyett milyen egyedi, személyre szóló marketing megoldások lehetnek sikeresek?

\section{Összegzés}

Írásomban nem a hagyományos értelemben vett vitairatformát választottam. Meggyőződésem, hogy a nemzetközi marketing fogalomrendszere a bekövetkezett társadalmi-technikai változások következtében átalakításra szorul. Úgy vélem, hogy több a kétség, mint a bizonyosság. Rekettye Gábor írása kitûnően mutatja be a nemzetközi marketing jelenét, s lényegében nem ébreszt kétségeket e terület szakmai jövőjével kapcsolatban. Számomra viszont a kételyek, a dilemmák a meghatározóak. Nem dönthetô el egyértelmúen a világgazdaság fejlődési iránya. Folyamatosan reménykedünk abban, hogy az egyes országok GDP-je dinamikusan fog növekedni, hogy az elmúlt évtizedek általános gazdasági felzárkózási folyamata megmarad, az unionista, a protekcionizmust lebontani akaró világgazdaság egyre jelentősebbé válik, miközben az elóbbiekkel ellentétes folyamatok is felfedezhetôk. Ezért gondolom úgy, hogy a nemzetközi marketing jövőjét az általam említett tényezók is mélyrehatóan és hosszú távon fogják befolyásolni, s ezért szerettem volna kiegészíteni az eredeti cikk gondolatait és megköszönni a lehetőséget. 


\section{Felhasznált irodalom}

Cateora, P.- Gilly, M.- Graham, J. (2013): International marketing. New York: McGraw-Hill

Czinkota, M.- Ronkainen, I. (2013): International marketing. Boston, MA: Cengage Learning

Kotler, P. (1972): Marketing Management. Upper Saddle River, NJ: Prentice Hall
Lauterborn, B. (1990): New Marketing Litany: Four Ps Passe C Words take over. Advertising Age, 61 (40): p. 26.

McCarthy, J. (1960): Basic Marketing. New York: Richard D. Irwin, Inc

Vargo, S. - Lusch, R. (2004): Evolving to a New Dominant Logic for Marketing. Journal of Marketing, Vol. 68 (January): p. 1-17. 